\title{
Effect of Licorice as an Alternative to Antibiotics on Productive, Egg Quality and Yolk and Blood Lipid Profile of Laying Japanese Quail
}

\author{
H. S. Zeweil, W. M. Dosoky*, S. M. Zahran, M. H. Ahmed and A. A. Mohamed \\ Department of Animal and Fish Production, Faculty of Agriculture (Saba Basha), \\ Alexandria University. \\ *Corresponding author: dosoky74@yahoo.com
}

\begin{abstract}
A total number of one hundred and eighty Japanese quail birds (120 females and 60 males), 9-weeks old were randomly divided into five groups, 36 birds each and each treatment was replicated four times with 9 birds in a completely randomized design. Dietary treatments were as follows: basal diet only without supplementation and served as a control group, basal diet $+100 \mathrm{mg}$ Tylosine $/ \mathrm{kg}$ diet, basal diet $+250 \mathrm{mg}$ licorice $/ \mathrm{kg}$ diet, basal diet $+500 \mathrm{mg}$ licorice $/ \mathrm{kg}$ diet and basal diet $+1000 \mathrm{mg}$ licorice $/ \mathrm{kg}$ diet. The results showed that dietary supplementation with different feed additives had insignificant effect on egg laying rate, egg number, average egg weight, egg mass and feed conversion ratio compared with control group. The percentage of egg shell thickness was significantly $(P \leq 0.001)$ increased by supplementation with Tylosine and licorice in compare with control group. Serum total lipids, total cholesterol and low density lipoprotein $(L D L)$ were significantly $(P \leq 0.001)$ decreased due to addition of different feed additives. Yolk total lipids was significantly $(P \leq 0.001)$ decreased with dietary supplementation of licorice root powder and Tylosin in the diets. Also, significant $(P \leq 0.01)$ decrease in egg yolk cholesterol was recorded in the group fed with $500 \mathrm{mg}$ licorice in comparison with anther treatments. In conclusion, dietary inclusion of licorice powder could be applied as alternatives to in-feed antibiotics for laying Japanese quail diets.
\end{abstract}

Key words: Quail, licorice, laying performance, egg quality, lipid profile

\section{INTRODUCTION}

The sub-therapeutic feeding of antibiotics has historically been a practice in some sectors of the broiler industry to promote growth performance and protect flock health (Landy et al., 2011). However, the use of dietary antibiotics has resulted in controversial problems such as development of antibiotic resistant bacteria and drug residue in the final products (Burgat, 1999) which can be harmful to consumers. Thus, the use of antibiotics as a growth promoter is no longer acceptable and it is forbidden in European Union countries. As a result, new alternatives are being introduced to livestock producers, among which phytogenic and herbal products have been considerable attention as possible in-feed antibiotics substitutions. In recent years, the use of phytogenic compounds has gained momentum for their potential role as natural alternatives to antibiotic growth promoters in animal nutrition (Zeweil et al., 2013; Landy et al., 2012). Herbs may contain some active substances that can trigger side effects and interact with other herbs, supplements, or medications. For these reasons, herbs should be taken with care, under the supervision-of a specialist in the field of botanical medicine. Herbs' spices and various plant extracts have proven to be possible candidates to 
J. Adv. Agric. Res. (Fac. Agric. Saba Basha)

replace antibiotic growth promoters in animal diets. Licorice, the root of the leguminous glycyrrhiza plant species, Glycyrrhiza glabra, (family Leguminosae) contains glycyrrhizin, glycyrrhetinic acid, flavonoids, asparagine, iso-flavonoids and chalcones. Licorice root has been used in Europe since prehistoric times, and its medicinal use is well documented (Fiore et al., 2005). Glycyrrhiza glabra, has been used as a medicinal product for over 4000 years. It has been reported that licorice has anti-microbial, anti-atherosclerotic, anti-oxidative, anti-inflammatory, oestrogen rich beverage anti-viral, anti-nephritic and radical scavenging activities (Fukai et al., 2003). Its root possesses some nutritive value and medicinal properties. They are widely used as a cold beverage, in preparing some pharmaceutical preparations such as hematinic pills and to disguise the bitter taste of other remedies (Shalaby et al., 2004). Therefore, this study aimed to investigate the effect of licorice on quality and quantity of egg production as well as blood lipid profile in Japanese quail laying hens.

\section{MATERIALS AND METHODS}

This study was carried out at the Poultry Research Laboratory belonging to Animal and Fish Production Department, Faculty of Agriculture (Saba Basha), Alexandria University. This study was undertaken during the period from May to July 2017. A total number of 180 Japanese quail birds (120 females and 60 males) at 9 weeks old were used. Quail were weighed individually, randomly distributed into five experimental groups, each group contained 36 birds (24 hens and 12 males); each one was subdivided into four replicates with 9 birds (6 hens and 3 males) in a completely randomized design. The birds were selected on basis of more than $60 \%$ egg production rate after one-week of observation period. Quail were housed in wire laying cages, ( 2 hens and 1 male); of an open house system throughout the experimental period which started at 9 weeks of age till 18 weeks of age. All birds were reared under similar hygienic and managerial conditions. Dietary treatments were as follows: basal diet only without supplementation and served as control, basal diet $+100 \mathrm{mg}$ antibiotic Tylosine $/ \mathrm{kg}$ diet, basal diet +250 $\mathrm{mg}$ licorice / $\mathrm{kg}$ diet, basal diet $+500 \mathrm{mg}$ licorice / $\mathrm{kg}$ diet and basal diet $+1000 \mathrm{mg}$ licorice / kg diet. Tylosine was obtained from Chemical Industries Development (CID) El-Tlbia-Pyramids-Giza-A.R.E-G.C.R19717- Giza, Egypt). Dried licorice was obtained from retail market, Alexandria, Egypt. All quail were reared in wire batteries under the same managerial, hygienic and environmental conditions. All laying hens were exposed to 16 hours of continuous light per day during the experimental period. Feed and water were available ad libitum throughout the 9week experimental period. The basal diet was formulated to meet the birds' dietary nutrient requirements (NRC, 1994). It contained $20 \%$ crude protein and $2894 \mathrm{kcal}$ $/ \mathrm{kg}$ metabolizable energy, the composition of basal diet is shown in Table 1. Body weight and feed consumption were recorded weekly. Feed conversion ratio was calculated (g feed / $\mathrm{g}$ egg). Egg laying rate, number of eggs and egg weight were monitored daily. Egg quality measurements were conducted using an average of 21 eggs from each treatment and were performed through two consecutive days 
per month. Shell thickness was determined from measurements of the mean thickness at three locations on the egg (air cell, equator and sharp end) using a dial pipe gauge (Mitutoyo, 0.01-20 mm, Tokyo, Japan). Yolk cholesterol was determined by nine eggs from each treatment and measured by the method of Folch et al. (1956) as modified by Washburn and Nix (1974). At the end of the experiment, blood samples were collected from the brachial vein of 4 hens randomly chosen from each group then serum were immediately centrifuged at 3500 r.p.m. for $15 \mathrm{~min}$. and stored at $-18^{\circ} \mathrm{C}$ until use. Serum and yolk lipid profile were colorimetrically determined using commercial kits (Biomerieux, Poains, France). The differences among treatments were statistically analyzed by one-way ANOVA using SPSS $®$ statistical software package for windows version 11.0. The significant differences between treatment means were separated by Duncan's Multiple Range-test (Duncan, 1955).

Table (1). Composition and calculated analysis of the basal experimental diet

\begin{tabular}{|c|c|}
\hline Ingredients & $\%$ \\
\hline Yellow corn & 53.58 \\
\hline Soybean meal (48\%) & 30.50 \\
\hline Di-calcium phosphate & 1.16 \\
\hline Limestone & 6.50 \\
\hline Lysin & 0.02 \\
\hline Wheat bran & 4.50 \\
\hline Sunflower oil & 3.00 \\
\hline Vit. and minreal. mix. ${ }^{* *}$ & 0.300 \\
\hline Salt (NaCl) & 0.300 \\
\hline Methionine & 0.139 \\
\hline Total & 100 \\
\hline \multicolumn{2}{|l|}{ Calculated analyses ${ }^{1}$ : } \\
\hline Crude protein, \% & 19.90 \\
\hline ME (Kcal/ kg diet) & 2894.42 \\
\hline Ether extract, \% & 2.48 \\
\hline Crude fiber, \% & 2.74 \\
\hline Methionine, \% & 0.45 \\
\hline Methionine + cystine, \% & 0.74 \\
\hline Lysine, \% & 1.01 \\
\hline Calcium, \% & 2.82 \\
\hline Av. Phosphorus & 0.38 \\
\hline
\end{tabular}




\section{RESULTS AND DISCUSSIONS}

Results presented in Table 2 showed that body weight change insignificantly affected by the different treatments. It should be pointed out that any gain in body weight after commencement of egg production should be minimal as the hen is essentially, at its mature body weight. Also, dietary supplementation with different feed additives had insignificant effect on egg laying rate, egg number (hen/day), average egg weight and egg mass ( $g / h e n / d a y)$ compared with those fed basal diet (control group) throughout the whole experimental period from 12-24 weeks of age. The best value in egg laying rate recorded in the group fed different feed additives compared with control group. Also, different feed additives had insignificant effect on feed consumption and feed conversion ratio of laying Japanese quail hens throughout the whole experimental period from 12-24 weeks of age as compared with control group.

In this respect, Doğan et al. (2018) reported that final live weight, was not affected by the licorice root powder supplementation $(P>0.05)$ of laying Japanese quail hens. While, Safari and Zahedi (2016) explained that 0, 0.5, 1, 1.5 and $2 \mathrm{~g} / \mathrm{kg}$ Glycyrrhiza glabra extract significantly influenced quail body weight during both the starter (1-21 days) and grower (21-42) periods of the study. Similarly, Myandoab and Mansoub (2012) investigated the effects of licorice root extract as a medicinal plant in quails. They obtained that average body weight gain increased in quails fed diet containing 200 ppm of licorice root extract and $1 \%$ probiotic in the diet.

Contrary to our study, Sedghi et al. (2010a) reported that diet supplemented with $4 \mathrm{~g} / \mathrm{kg}$ of licorice extract had greater $(P<0.05)$ egg production than the control group fed diet during the experiment. Also, Awadein et al. (2010) reported that dietary supplementation of licorice at the level of 0.1 and $0.5 \%$ had significant effect on egg weight and egg production in Mandarah hens. They explained that egg weight increased with dietary licorice supplementation $(P<0.05)$. Also, Aghdam Shahryar et al. (2018) reported that licorice powder supplementation significantly affect the performance of Hy-Line $\mathrm{W}-36$ layer hens $(\mathrm{P}<0.01)$. The highest values of egg production $(60.96 \%)$, egg weight $(61.50 \mathrm{~g})$ and egg mass $(37.60 \mathrm{~g})$.

Doğan et al. (2018) found that egg weight was not affected by the licorice root powder supplementation ( $P>0.05$ ) of laying Japanese quail hens. Also, Sedghi et al. (2010a) showed that diets supplemented with $0,2,4$ or $6 \mathrm{~g} / \mathrm{kg}$ of licorice extract was not influenced the egg weight in 58-weeks-old laying hens.

Glycyrrhizin (10-25\%) is the main compound that is found in large amount in the root of licorice (Nowakowska, 2006). Glycyrrhizin is a phytobiotic compound with antiviral and anti-bacterial properties (Brenes and Roura, 2010). So, use of it in hen diets may be improving their performance via reducing the amount of harmful digestive tract microorganisms (Khamisabadi et al., 2014.) 
In another study it was shown that the phytobiotic compounds such as glycyrrhizin are able to activate the mechanisms of sensory peripheral in the cavities of the mouth and nose, the gut to receive feed and also stimulate gastrointestinal motility and secretions of the stomach for best digestion of feed ingredients (Vaya et al., 1997). Herbs with growth promoting activity increased the stability of feed and beneficially influence the gastrointestinal ecosystem mostly through growth inhibition of pathogenic microorganism's growth (Windisch et al. 2008). Therefore, it might be possible that the increase of digestion and absorption of essential nutrients due to increasing the enzyme activity and / or inhibition of pathogenic microorganism's growth could be the main reason of licorice medicine plant to accelerate the performance. Previous studies with other species of animals have shown that licorice flavonoids suppress body weight (BW) by reducing body fat mass (Armanini et al., 2002; Nakagawa et al., 2004; Tominaga et al., 2006; Aoki et al., 2007). Indeed, increase of digestion and absorption of essential nutrients and increasing the availability and utilization of feed ingredients' energy and exist of sterols plant might lead to increased egg production in group 5 by using $2 \%$ powder licorice medicine plant.

Safari and Zahedi (2016) explained that 0, 0.5, 1, 1.5 and $2 \mathrm{~g} / \mathrm{kg}$ Glycyrrhiza glabra extract significantly $(P<0.05)$ influenced quail feed intake during both the starter (1-21 days) and grower (21-42) periods of the study, but there was not any significant $(P>0.05)$ effect on feed conversion ratio during the experiment. Similarly, Myandoab and Mansoub (2012) investigated the effects of licorice root extract as a medicinal plants and probiotic in quails. They obtained that feed conversion ratio decreased and feed intake increased in quails fed containing 200 ppm of licorice root extract and $1 \%$ probiotic in the diet.

There is a very limited number of studies have been conducted on the use of licorice root powder or extract as supplement in laying hens and quail diets. The different results may be due to the different species of poultry or different form of licorice used in the researches. Experiment on the addition of licorice root was made mostly on broiler chickens and the findings were compared with them.

The results in Table (3) showed that egg weight, percentage of egg shell weight were not significantly affected, while the absolute shell weight was significantly $(P \leq 0.05)$ affected by the different feed additives compare with control group, egg specific gravity was insignificantly $(P \leq 0.05)$ affected by the different feed additives compare with control group. Also, egg shell thickness was significantly $(P \leq 0.05)$ increased by supplementation of Tylosin and different treatments of licorice root powder compare with control group.

Table (3) also showed that albumen weight and height and yolk index and yolk color were insignificantly affected by different treatments. On the other hand, absolute and relative yolk weight and percentage of albumen weight were significantly affected by the different treatments in compare with control group. The 
best values of absolute and relative yolk weight were recorded in the three different treatments of licorice root powder in their diets compare with Tylosin and control group, while the best value of percentage of albumen weight was recorded in the group had $1000 \mathrm{mg}$ licorice and control group in their diets. In the present study, diet supplementation by licorice had no significant impact on most of the egg quality traits of the laying hens. We have found no study showing the action mechanism of licorice on egg quality characteristics in the literature to compare our result, except the paper of Aghdam Shahryar et al. (2018) result, licorice powder in laying diets significantly effects on yolk weight $(P<0.05)$, shell thickness, Hugh unit and yolk color in laying hens $(\mathrm{P}<0.01)$ and also, $\mathrm{Al}$ - Daraji et al. (2009) revealed that feeding the birds diet contains different levels of licorice extract $(250,500$ and 750) $\mathrm{mg}$ licorice/kg diet resulted in significant improvement as regards egg weight, yolk diameter, yolk height, albumen height, yolk weight, shell weight, shell thickness and Hugh unit during the most periods of this experiment and concerning the general means of these traits. This is consistent with data from Sedghi et al. (2010a) who reported that using licorice could not change the egg traits except egg shell thickness. Ghasemi et al. (2010) who reported that yolk color responded linearly with increasing levels of medicinal herbs. Poltowicz and Wezyk (2001) had also showed that the herbs used significantly increased yolk color intensity in the experimental groups.

Concerning lipid profile in the serum, Table (4) represents the results of the effects of different feed additives on serum total lipids, total cholesterol, LDL, HDL concentrations and HDL/LDL ratio of birds.

Results indicated that serum total lipids, total cholesterol, and LDL concentrations were significantly $(P \leq 0.001)$ decreased due to addition of different feed additives, however, HDL concentrations and HDL/LDL ratio were significantly $(P \leq 0.001)$ increased by the different treatments as compared with control group. Total lipids recorded the lowest values in the group fed $500 \mathrm{mg}$ licorice. Also, total cholesterol and LDL concentrations were recorded the lowest values in the group fed diets with 1000 and $500 \mathrm{mg}$ licorice /kg respectively. However, HDL concentrations recorded the highest value with addition of $250 \mathrm{mg}$ licorice $/ \mathrm{kg}$ diet.

In agreement with our results, Doğan et al. (2018) reported that Licorice root powder supplementation to the experimental diets decreased the LDL concentration and $1.0 \%$ licorice root powder supplemented group had the lowest LDL level. Also, Sedghi et al. (2010b) who explained that licorice extracts at the levels of $0.5,1.0$ and $2.0 \mathrm{~g} / \mathrm{kg}$ decreased cholesterol and triglyceride concentration and increased HDL concentration in broilers. Sharifi et al. (2013) reported that the increase in plasma HDL levels may be due to the inhibition of the active enzyme hepatic 3-hydroxy-3-methylglutaryl-coenzyme A (HMG-COA). The enzyme 3hydroxy-3-methylglutaryl-coenzyme A (HMG-CoA) reductase is the rate-limiting enzyme in cholesterol biosynthesis that catalyzes the conversion of HMG-CoA (Friesen and Rodwell, 2004). Indeed, it is suggested that medicinal plants cause a 
decrease in HMG-COA enzyme synthesis (Yu et al., 1998). Results of the present study for serum cholesterol and triglyceride concentrations agree with Al-Daraji, (2012); Myandoab and Mansoub (2012) and Rezaei et al. (2014). Myandoab and Mansoub (2012) reported that the levels of serum cholesterol and triglyceride concentrations reduced with licorice root supplementation in quail diets. In contrast to our results, Salary et al. (2014) stated that the inclusion of 0.2 and $0.4 \%$ licorice extracts in drinking water of broiler did not decreased triglyceride and cholesterol levels. Asgary et al. (2007) have revealed that G. glabra extract has an effect of on the blood lipids and atherosclerosis. These workers have found that G. glabra extract significantly decreases total cholesterol (TC), low-density lipoprotein cholesterol (LDL-C), and triglyceride (TG) levels and increases high-density lipoprotein cholesterol (HDL-C) and lessens atherosclerotic lesion in aorta.

Table (4) also showed that yolk total lipids was significantly $(P \leq 0.01)$ decreased with dietary supplementation of licorice root powder and Tylosin in the diets. The lowest value $(P \leq 0.01)$ of yolk total lipids was recorded in the groups had $250 \mathrm{mg}$ licorice root powder, followed by $500 \mathrm{mg}$ licorice, Tylosin and $1000 \mathrm{mg}$ licorice ascending order, respectively, as compare with the control group. The aforementioned groups showed significant decrease in compare with the control group to reach $23.71,23.15,22.03,11.34$, respectively. Also, significant $(P \leq 0.01)$ decrease in egg yolk cholesterol was recorded in the groups fed $500 \mathrm{mg}$ licorice in comparison with another treatment.

No studies showing the action mechanism of licorice on egg yolk lipid profile in the literature to compare our result except, Doğan et al. (2018) who reported that serum and egg yolk cholesterol levels significant $(P \leq 0.01)$ decrease with increasing level of licorice root powder supplementation at the 4th and 8th weeks. Awadein et al. (2010) stated that 0.1 and $0.5 \%$ licorice root as a source of phytoestrogens in the layers diets significant $(P \leq 0.01)$ decrease egg cholesterol levels than the control group.

In conclusion, the results suggested that dietary licorice root powder have the ability to maintain normal performance as using antibiotics comparing to the control. 
Table (2). Performance of laying Japanese quail hens fed on the experimental diets

\begin{tabular}{|c|c|c|c|c|c|c|}
\hline \multirow[b]{2}{*}{ Parameters } & \multicolumn{5}{|c|}{ Treatments } & \multirow{2}{*}{$\begin{array}{c}P \\
\text { Value }\end{array}$} \\
\hline & Control & $\begin{array}{l}\text { Tylosin (100 } \\
\text { mg/kg diet) }\end{array}$ & $\begin{array}{c}\text { licorice (250 } \\
\mathrm{mg} / \mathrm{kg} \text { diet) }\end{array}$ & $\begin{array}{c}\text { licorice (500 } \\
\text { mg/kg diet) }\end{array}$ & $\begin{array}{c}\text { licorice (1000 } \\
\text { mg/kg diet) }\end{array}$ & \\
\hline \multicolumn{7}{|l|}{ Laying performance: } \\
\hline Body weight change, g & $15.73 \pm 1.76$ & $20.63 \pm 4.62$ & $19.72 \pm 4.93$ & $15.35 \pm 3.45$ & $16.40 \pm 2.58$ & 0.778 \\
\hline Egg laying rate $\%$, hen-day & $69.11 \pm 4.83$ & $74.86 \pm 1.47$ & $76.52 \pm 2.54$ & $77.70 \pm 3.25$ & $75.13 \pm 2.55$ & 0.402 \\
\hline Egg number, hen/day & $0.69 \pm 0.04$ & $0.75 \pm 0.01$ & $0.76 \pm 0.02$ & $0.78 \pm 0.03$ & $0.75 \pm 0.02$ & 0.398 \\
\hline Mean egg weight, $g$ & $11.99 \pm 0.25$ & $12.40 \pm 0.03$ & $12.49 \pm 0.06$ & $12.35 \pm 0.07$ & $12.31 \pm 0.26$ & 0.349 \\
\hline Egg mass/hen/day, g & $8.28 \pm 0.56$ & $9.28 \pm 0.20$ & $9.55 \pm 0.27$ & $9.60 \pm 0.44$ & $9.24 \pm 0.23$ & 0.161 \\
\hline Feed consumed/hen /day, g & $30.01 \pm 1.03$ & $30.27 \pm 0.06$ & $32.00 \pm 0.81$ & $30.01 \pm 0.64$ & $31.36 \pm 0.29$ & 0.202 \\
\hline Feed conversion ratio & $3.65 \pm 0.25$ & $3.26 \pm 0.06$ & $3.35 \pm 0.04$ & $3.14 \pm 0.10$ & $3.40 \pm 0.10$ & 0.169 \\
\hline
\end{tabular}


Table (3). Egg quality traits of laying Japanese quail hens fed on the experimental diets

\begin{tabular}{|c|c|c|c|c|c|c|}
\hline \multirow[b]{2}{*}{ Parameters } & \multicolumn{5}{|c|}{ Treatments } & \multirow{2}{*}{$\begin{array}{c}P \\
\text { Value }\end{array}$} \\
\hline & Control & $\begin{array}{l}\text { Tylosin (100 } \\
\text { mg/kg diet) }\end{array}$ & $\begin{array}{l}\text { licorice (250 } \\
\text { mg/kg diet) }\end{array}$ & $\begin{array}{l}\text { licorice (500 } \\
\mathrm{mg} / \mathrm{kg} \text { diet) }\end{array}$ & $\begin{array}{c}\text { licorice (1000 } \\
\mathrm{mg} / \mathrm{kg} \text { diet) }\end{array}$ & \\
\hline \multicolumn{7}{|l|}{ Egg quality: } \\
\hline Egg weight, g & $11.91 \pm 0.27$ & $12.61 \pm 0.36$ & $12.51 \pm 0.39$ & $12.68 \pm 0.27$ & $12.04 \pm 0.39$ & 0.396 \\
\hline Egg specific gravity & $1.076^{\mathrm{ab}} \pm 0.001$ & $1.076^{\mathrm{ab}} \pm 0.001$ & $1.074^{b} \pm 0.001$ & $1.079^{a} \pm 0.001$ & $1.079^{\mathrm{a}} \pm 0.001$ & 0.046 \\
\hline Albumen height, mm & $3.30 \pm 0.26$ & $2.84 \pm 0.12$ & $3.02 \pm 0.13$ & $2.94 \pm 0.15$ & $2.99 \pm 0.21$ & 0.520 \\
\hline Albumen weight, $g$ & $7.15 \pm 0.17$ & $7.30 \pm 0.22$ & $7.26 \pm 0.23$ & $7.30 \pm 0.20$ & $7.06 \pm 0.22$ & 0.906 \\
\hline Albumen weight, $\%$ & $59.99 \pm 0.24$ & $57.90 \pm 0.63$ & $58.00 \pm 0.56$ & $57.52 \pm 0.85$ & $58.65 \pm 0.65$ & 0.062 \\
\hline Yolk weight, g & $3.67 \pm 0.08$ & $4.13 \pm 0.17$ & $4.13 \pm 0.17$ & $4.18 \pm 0.12$ & $3.85 \pm 0.17$ & 0.066 \\
\hline Yolk weight,\% & $30.79 \pm 0.19$ & $32.95 \pm 0.65$ & $32.97 \pm 0.62$ & $32.98 \pm 0.89$ & $31.88 \pm 0.66$ & 0.080 \\
\hline Yolk color & $3.78 \pm 0.22$ & $3.44 \pm 0.17$ & $3.56 \pm 0.24$ & $3.44 \pm 0.24$ & $3.67 \pm 0.28$ & 0.826 \\
\hline Yolk index & $434.38 \pm 11.62$ & $419.60 \pm 14.84$ & $433.35 \pm 10.26$ & $432.26 \pm 12.32$ & $448.40 \pm 14.46$ & 0.640 \\
\hline Egg shell weight, g & $1.10 \pm 0.03$ & $1.15 \pm 0.03$ & $1.12 \pm 0.02$ & $1.20 \pm 0.04$ & $1.14 \pm 0.04$ & 0.224 \\
\hline Egg Shell weight, \% & $9.22 \pm 0.18$ & $9.15 \pm 0.12$ & $9.02 \pm 0.19$ & $9.50 \pm 0.26$ & $10.47 \pm 0.29$ & 0.406 \\
\hline Egg shell thickness, $\mathrm{mm}$ & $0.234^{b} \pm 0.009$ & $0.280^{\mathrm{a}} \pm 0.007$ & $0.287^{a} \pm 0.011$ & $0.272^{\mathrm{a}} \pm 0.008$ & $0.283^{a} \pm 0.007$ & 0.001 \\
\hline
\end{tabular}


Table (4). Serum and egg yolk lipid profile of laying Japanese quail hens fed on the experimental diets

\begin{tabular}{lcccccc}
\hline & \multicolumn{5}{c}{ Treatments } \\
\cline { 2 - 7 } \multicolumn{1}{c}{ Parameters } & Control & $\begin{array}{c}\text { Tylosin (100 } \\
\text { mg/kg diet) }\end{array}$ & $\begin{array}{c}\text { licorice (250 } \\
\text { mg/kg diet) }\end{array}$ & $\begin{array}{c}\text { licorice (500 } \\
\text { mg/kg diet) }\end{array}$ & $\begin{array}{c}\text { licorice (1000 } \\
\text { mg/kg diet) }\end{array}$ \\
\hline Serum lipid profile: & & & & & \\
Total Lipid, mg/dl & $452.62^{\mathrm{a}} \pm 11.54$ & $322.98^{\mathrm{b}} \pm 5.23$ & $269.19^{\mathrm{bc}} \pm 8.81$ & $255.97^{\mathrm{c}} \pm 15.27$ & $285.97^{\mathrm{bc}} \pm 8.44$ & 0.001 \\
Cholesterol, mg/dl & $195.67^{\mathrm{a}} \pm 2.40$ & $182.33^{\mathrm{b}} \pm 1.45$ & $179.67^{\mathrm{bc}} \pm 0.66$ & $182.67^{\mathrm{b}} \pm 1.76$ & $176.33^{\mathrm{c}} \pm 1.45$ & 0.001 \\
HDL,mg/dl & $84.67^{\mathrm{c}} \pm 2.72$ & $89.33^{\mathrm{ab}} \pm 0.33$ & $91.67^{\mathrm{a}} \pm 0.88$ & $91.00^{\mathrm{a}} \pm 0.57$ & $86.00^{\mathrm{bc}} \pm 0.57$ & 0.015 \\
LDL,mg/dl & $55.33^{\mathrm{a}} \pm 0.33$ & $46.67^{\mathrm{b}} \pm 0.66$ & $47.33^{\mathrm{b}} \pm 0.33$ & $46.33^{\mathrm{b}} \pm 0.66$ & $48.33^{\mathrm{b}} \pm 1.76$ & 0.001 \\
HDL/LDL ratio & $1.53^{\mathrm{c}} \pm 0.05$ & $1.93^{\mathrm{a}} \pm 0.02$ & $1.95^{\mathrm{a}} \pm 0.02$ & $1.97^{\mathrm{a}} \pm 0.01$ & $1.80^{\mathrm{b}} \pm 0.05$ & 0.001 \\
\hline Yolk lipid profile: & & & & & & \\
Total Lipid, mg/dl & $355.67^{\mathrm{a}} \pm 9.83$ & $277.33^{\mathrm{c}} \pm 6.69$ & $271.33^{\mathrm{c}} \pm 9.59$ & $273.33^{\mathrm{c}} \pm 4.41$ & $315.33^{\mathrm{b}} \pm 4.84$ & 0.001 \\
Cholesterol, mg/dl & $18.65^{\mathrm{a}} \pm 0.33$ & $18.74^{\mathrm{a}} \pm 0.13$ & $18.30^{\mathrm{a}} \pm 0.22$ & $16.75^{\mathrm{b}} \pm 0.30$ & $18.50^{\mathrm{a}} \pm 0.42$ & 0.005 \\
\hline
\end{tabular}


J. Adv. Agric. Res. (Fac. Agric. Saba Basha)

\section{REFERENCES}

Al-Daraji, H. J. (2012). Influence of drinking water supplementation with licorice extract on certain blood traits of broiler chickens during heat stress. Report and Opinion, 4(9): 56-60.

Al- Darajj, H. J. W.K. Al - Hayani, H. A. Al - Mashadani and D. H. Al Hassani. (2009). The use of different concentrations of licorice extract (Glycyrrhiza glabra) for improving egg quality traits of Lohmann hens reared during different periods of the year. Alfurat. J. Agric. Sci., 1 (2): $71-80$.

Aghdam Shahryar, M., A. Ahmadzadeh and A. Nobakht (2018). Effects of Different Levels of Licorice (Glycyrrhiza glabra) Medicinal Plant Powder on Performance, Egg Quality and some of Serum Biochemical Parameters in Laying Hens. Iranian Journal of Applied Animal Science, 8(1): 119-124.

Aoki, F., S. Honda, H. Kishida, M. Kitano, N. Arai and H. Tanaka (2007). Suppression by licorice flavonoids of abdominal fat accumulation and body weight gain in high-fat diet-induced obese C57BL/6Jmice. Biosci. Biotechnol. Biochem., 71(1): 206-214.

Armanini, D., C. Fiore, M. J. Mattarello, J. Bielenberg and M. Palermo (2002). History of the endocrine effects of licorice. Exp. Clin. Endocrinol. Diabetes., 110(6): 257-261.

Asgary, S., N. Jafari Dinani, H. Madani, P. Mahzoni and G. H. Naderi (2007). Effect of Glycyrrhiza glabra extract on aorta wall atherosclerotic lesion in hypercholesterolemic rabbits. Pak J Nutr, 6(4): 313-7.

Awadein, N. B., Y.Z. Eid and F. A. Abd El-Ghany (2010). Effect of dietary supplementation with phytoestrogens sources before sexual maturity on productive performance of Mandarah hens. Egyptian Poultry Science, 30(3): 829-846.

Brenes, A.T. and E. Roura (2010). Essential oils in poultry nutri-tion: Main effects and modes of action. Anim. Feed Sci. Tech-nol., 158:1-14.

Burgat, V. (1999). Residues of drugs of veterinary use in food. Rev. prat. 41:985990.

Doğan, S. C., M. Baylan, S. Yaman and A. Bulancak (2018). Effects of dietary licorice root (Glycyrrhriza glabra) supplementation, storage time and temperature on quality of quail eggs. Progress in Nutrition, 20 (4): 665-671.

Duncan, D.B. (1955). Multiple Range and Multiple F- test. Biometrics., 11 : 1-42.

Fiore C, M. Eisenhut, E. Ragazzi, G. Zanchin and D. Armanini (2005). A history of the therapeutic use of liquorice in Europe. J. Ethnopharmacol, 99: 317-24.

Folch, J., M. Less and G. H. Solane Stanley (1956). A simple method for the isolation and purification of total lipids from animal tissues. J. Bio. Chem., 226: 497- 509.

Friesen, J. A.and V.W. Rodwell (2004).The 3-hydroxy-3- methylglutaryl coenzyme-A (HMG-CoA) reductases. Genome Biol., 5(11): 248.

Fukai, T., K. Satoh, T. Namura and H. Sakagami(2003). Ant nephritis and radical scavenging activity of prenylflavonoids. Fitoterapia, 74: 720-754. 
Ghasemi, R., M. Zarei and M. Torki (2010). Adding medicinal herbs including garlic (Allium sativum) and thyme (Thymus vulgaris) to diet of laying hens and evaluating productive per-formance and egg quality characterisctis. Asian J. Anim. Vet. Sci., 5:151-154.Journal of Animal Science, 3(2): 41-48.

Landy, N., G.H Ghalamkari and M. Toghyani (2012). Evaluation of St John's Wort (Hypericum perforatum L.) as an antibiotic growth promoter substitution on perform- ance, carcass characteristics, some of the immune responses, and serum biochemical parameters of broiler chicks. Journal of Medicinal Plants Research, 6: 510-515. doi:10.5897/JMPR11.1371.

Landy, N., G. Ghalamkari and M. Toghyani (2011). Performance, carcass characteristics, and immunity in broiler chickens fed dietary neem (Azadirachta Indica) as alternative for an antibiotic growth promoter. Livest Sci., 142:305-309.

Khamisabadi, H., G. Pourhesabi, B. Chaharaein and R. Nasiri (2014). Coparision of the effect of licorice extract and linco-mycine on abdominal fat, biochemical blood parameters and immunity of broiler chickens. Anim. Sci. J. (Pajouhesh and Sazandeghi). 105, 229-244.

Myandoab, M.P. and N.H. Mansoub (2012). Comparative effect of Liquorice root extract medicinal plants and probiotic in diets on performance, carcass traits and serum composition of Japanese Quails. Global Veterinarian, 8(1):39-42.

Nakagawa, K., H. Kishida, N. Arai, T. Nishiyama and T. Mae (2004). Licorice flavonoids suppress abdominal fat accumulation and increase in blood glucose level in obese diabetic KK-A(y) mice. Biol. Pharm. Bull., 27(11): 1775-1778.

Nowakowska, Z. (2006). A review of anti-infective and anti-inflammatory chalcones. Eur. J. Med. Chem., 42:125-137.

NRC (1994). Nutrition Requirement of Poultry, ( $9^{\text {th }}$ Rev. Eds), National Academy Press, Washington DC.

Poltowicz, K. and S. Wezyk (2001). Effect of herb supplementation in the feeding of laying hens on their productivity and egg quality. Roczniki. Nauk. Zootech., 28: 215-225.

Rezaei, M., M. Kalantar and J. Nasr (2014). Thymus Vulgaris L., Glycyrrhiza Glabra, and Combo Enzyme in Corn or Barley- Basal Diets in Broiler Chickens. International Journal of Plant, Animal and Environmental Sciences, 4(3): 418-423.

Safari, A. and A. Zahedi (2016). The effect of different levels supplementation of Glycyrrhiza glabra extract on growth performance in male quail. International Journal of Advanced Biological and Biomedical Research, 4(2):214-219.

Salary, J., M. Kalantar, M.K. Sahebi ala, K. Ranjbar and H. R. Hemati Matin (2014). Drinking water supplementation of licorice and aloe vera extracts in broiler chickens. Scientific Journal of Animal Science, 3(2): 41-48.

Sedghi, M., A.G.H. Golian and P. Soleymani (2010a). Effect of Dietary Supplementation of Licorice Extract on Egg Quality and Performance of Hens. Veterinary Clininal Pathology, 4(15):933-941. 
Sedghi, M., A. Golian, H. Kermanshahi and H. Ahmadi (2010b). Effect of dietary supplementation of licorice extract and a pre-biotic on performance and blood metabolites of broilers. South African J. Anim. Sci. 40(4): 371-380.

Shalaby, M.A., H.S. Ibrahim, E. M. Mahmoud and A. F. Mahmoud (2004). Some effects of glycyrrhiza glabra (liquorice) roots extract on male rats. Egypt J Natural Toxins., 1:83-94.

Sharifi, S.D., H. Saeedeh, A. Khorsandi, A. Khadem, A. Salehi and H.R. Moslehi (2013). The effect of four medicinal plants on the performance, blood biochemical traits and ileal microflora of broiler chicks. Veterinarski arhiv, 83(1):69-80.

Tominaga, Y., M. Tatsumasa, K. Mitsuaki, S. Yoshiro, I.Hideyuki and N. Nakagawa (2006). Licorice flavonoid oil effect body weight loss by reduction of body fat mass in overweight sub-ject. J. Hith. Sci., 52(6): 672-683.

Vaya, J., P.A. Belinky and M. Aviram (1997). Antioxidant constituents from licorice roots isolation, structure elucidation and antioxidative capacity toward LDL oxidation. Free Radic. Biol. Med., 23(2): 302-313.

Washburn, K.W. and D. F. Nix (1974). A rapid technique for extraction of yolk cholesterol. J. Poult. Sci., 53: 1118-1122.

Windisch, W. Schedle, K. Plitzner, C. and A. Kroismayer (2008). Use of phytogenetic products as feed additives for swine and poultry. J. Anim. Sci., 86: $140-148$.

Yu, S.G., J.C. Hsu and P. W. S. Chiou (1998). Effects of $\beta$-glucanase supplementation of barley diets on growth performance of broilers. Animal Feed Science and Technology, 70:353-361.

Zeweil, H. S., R. E. Rizk, M. H. Abd El- Rahman, A. Nadia Mohamed and E. Ebtesam Iraky (2013). Influence of dietary linseed oil and selenium supplementation on productive and reproductive performance of Bandarah chickens. $11^{\text {th }}$ World Conference on Animal Production, Beijing, China, 1520 October 2013. 
الملخص العربي

\section{تأثير العرقسوب كبديل للمضادات الحيوية على الأداء الإنتاجي وجودة البيض ومحتوى الصفار والام من الدهون في السمان الياباني البياض}

\section{حسن صابر زويل ، وليا مصطفى دسوقي، سليمان محمد زهران ، محمد حسن احمد، عبدالله على محمد}

قسم الانتاج الحيواني والسمكي - كلية الزراعة سابا باشنا- جامعة الإسكندرية.

استخدم ،11 طائر عمر 9 أسبوع تم توزيعهم عشوائيا في تصميم عشوائي كامل علي خمس معاملات تجريبية وكل

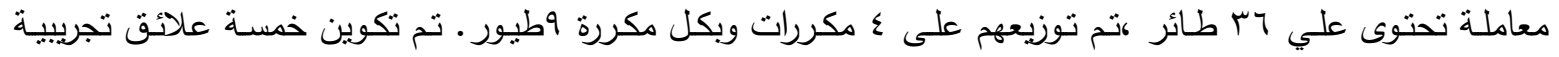
كالتالي: المعاملة الأولى غذيت الطيور على عليقة أساسية بدون أب أضافات واستخدمت كمجموعة كنترول. المعاملة

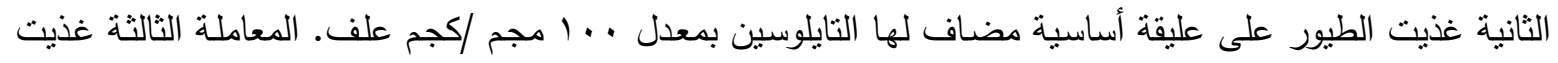
الطيور على عليقة اساسية مضاف لها العرقسوس بمعدل • ro مجم /كجم علف. المعاملة الرابعة غذيت الطيور على على عليقة اساسية مضـاف لها العرقسوس بمعدل . .0 مجم /كجم علف. المعاملـة الخامسـة غذيت الطيور على عليقة اساسية مضاف لها العرقسوس بمعدل .... . مجم /كجم علف. وكانت اهم النتائج المتحصل عليها كالاتي: معدل التغير فى وزن الجسم لم يتغير معنويا نتيجة الاضافات الغذائية من اصل نباتي مقارنة مع مجموعة الكنترول. سجلت أفضل قيم لمعدل وضع البيض، عدد البيض، ومتوسط وزن البيضة، وكتلة البيض، ومعامل التحويل الغذائي في المجموعات التي تتاولت العرقسوس وتلاها المجموعة المغذاة على المضاد الحيوي مقارنة مع الكنترول. زادت معنويا سمك قثرة البيض نتيجة استخدام الإضافات العلفية من اصل نباتي وايضا المضاد الحيوي مقارنة مع الكونترول. انخفضت الدهون الكلية والكولسنرول الكلى معنويا في سيرم الدم وفى صفار البيضة نتيجة للإضافات المختلفة. المعاملات المختلفة اثرت معنويا في HDL, LDL ولوحظ ان إضافة العرقسوس خفض معنويا من تركيز LDL وزاد معنويا نزكيز HDL مقارنة بالكنترول. ولم تتأثز معنويا النسبة HDL/LDL بالإضافات المختلفة. و خلصت الدراسة الى انه يمكن استخدام العرقسوس كبديل للمضادات الحيوية في تغذية السمان الياباني البياض. 